\title{
EDUCATION QUALITY IN PUBLIC SCHOOLS: AN EXPERIMENT TO REDUCE THE AGE-GRADE GAP IN THE CITY OF RIO DE JANEIRO
}

\author{
Alice Xavier, Maria Luiza Canedo \\ Pontifical Catholic University of Rio de Janeiro, Brazil \\ E-mail: alicepx@yahoo.com.br, luiza.canedo@uol.com.br
}

\begin{abstract}
This article developes a critical reflection about a learning acceleration project facing the senior students of fundamental education ${ }^{1}$. The project entitled Autonomia Carioca was prepared by a private institution and recently introduced in public schools of Rio de Janeiro, in the perspective of public-private partnership. The Project proposal is based on teacher training to deal with different languages, emphasizing the values construction, the self-esteem recovery and the study habits formation. Facing the challenge of dropout, 8500 students concluded the first stage of elementary education. This paper describes the objectives and methodology of the Project and also analyze work field observations and school principal interviews in a school in order to discuss challenges and opportunities. From the proposal of the Project to its implementation in the classroom, many factors were involved in the task of teaching the students who did not succeed in the traditional education. Some aspects discussed in this case study are: school director support, pedagogical attendance, teacher profile identification, classes' arrangement, partnership with families and distinguished accompanying of students. The results point to the joint action of school agents as a determining factor for the success of the work.
\end{abstract}

Key words: age-grade gap, education quality, learning acceleration, public-private partnership.

\section{Introduction}

It is recognized the strategic importance of basic education for the quality of schooling as a whole, and this segment is defined as the minimum schooling necessary for both exercising citizenship and for future access to the labor market, which is increasing its demand for education degrees.

Although Brazil has already reached the universalization of the access to Fundamental Education, the conclusion of this stage and the quality of education are still challenging objectives. The 2007 National Household Sample Survey (PNAD 2007) indicated that in the last year of fundamental school, $44 \%$ of the students had more than 14 years old and $11 \%$ more than 18 years old revealing that the goal of completing the fundamental school at the age of 14 years was still far from being achieved. According to the 2009 census, the city of Rio the Janeiro had 355.307 adolescents in the 11-14 age group, $27 \%$ of which $(98,549)$ were enrolled in the private school network while $73 \%(257,758)$ used the public school network. Among the latter, 249,502 were enrolled in the municipal system and 405 schools offered the second segment of fundamental education.

As part of a research group ${ }^{2}$ which has been investigating the quality of education for more than 10 years, we were faced with a new project designed for students with age-grade gap, in one of the public schools. Since 2009, we have been using questionnaires and conducting 
PROBLEMS

OF EDUCATION

IN THE $21^{\text {st }}$ CENTURY

Volume 40, 2012

interviews with school agents in this public unit. Managers' and teachers' spontaneous comments have called our attention to the "Projeto Autonomia Carioca". During 2011, this school was visited in different occasions in order to observe students activities, parent-teacher meetings, events and interactions of teachers and managers with parents and students. In addition, we conducted semi-structured interviews with the principal, the school coordinator and teachers directly involved with the Project. The present study was developed focusing on students, teachers, managers and parents in different moments of school life.

In this article we present a reflection on a Project to speed-up the learning process while we describe its objectives and characteristics. Using interviews with school agents and field notes made during 2011, we analyze the way a public school has appropriated and developed this Project work over 2 years. The content analysis was used as methodology to interpret the testimonies.

\section{Acceleration Learning Project: A Public-Private Partnership}

Facing the challenge of building the education quality for all students the Municipal Education Secretariat (EMS) has been encouraging the participation of civil society, expanding actions developed in partnership with private institutions. The current local government has been emphasizing these partnerships even though they are not new in Brazilian public policies.

The "Projeto Autonomia Carioca" was one of the initiatives implemented in 205 public schools. The Project started in 2010 to address the age-grade gap equal or greater than to 2 years for students enrolled in the last grades of fundamental school.

The Project which main goal is to gradually reduce the age-grade gap was designed by a private institution ${ }^{3}$ responsible for developing the methodology and educational material, and training teachers, in addition to following up the process in the schools. After training the teachers and delivering the material, one of the school teachers develops the work in the classroom assuming the responsibility for teaching all disciplines of the school curriculum, in modules. Shortening the time required for this education stage and working with the selfesteem, students are encouraged to continue their schooling.

The educational material developed by the private institution and produced in centers of excellence of Brazilian universities contains textbooks, supporting texts and video classes, which are exhibited for the students. It was developed 9 books for students, 6 books for teachers and 360 television programs for fundamental education, distributed in three modules.

It's up to the school management organize the class and allocate students from the school itself and from other public units, who have recurrent learning difficulties and are candidates for repeating or drop-outs. These classes, with students in the 13-16 age group receive special attention from the teacher and managers regarding school attendance, tasks performance, behavior in classroom and interaction with colleagues and teachers.

\section{The Project in the View of Educational Agents: A Case Study}

The municipal school, used as the basis for this study was inaugurated in 1933. It is located in Rio de Janeiro close to some of the main tourist attractions of the city and situated in an adapted building, setting physical limits to educational activity.

However, restrictions caused by the lack of infrastructure and professionals shortage don't seem to prevent the management team from putting in place actions that over time have contributed to rise the school to the highest levels of performance in relation to other schools of the network.

Led by a school management committed and legitimized by successive reelections, implementing partnerships and participating in several projects have been the core strategy for 
building education quality since 1988. The school has also taken part in academic and sports competitions in which students have the opportunity to show their knowledge. The good results

PROBLEMS

OF EDUCATION

IN THE $211^{\text {st }}$ CENTURY

Volume 40,2012 achieved by the students brought visibility and recognition to the school, attracting a more interested group of students and families committed to education. But, it also brought students whose families believed finding there the assistance they needed. The School Coordinator speaks about the varied social composition, stating that "there is a group of students that ensures the school reputation, dedicating themselves to entrance examinations to federal public schools and to scholarships in private schools".

If the majority of the school students succeed in internal and external evaluations, there are some students that "for various reasons are left behind, out of their age group", says the Principal. The initial strategy used to set up a class of repeaters seemed "not work". Marked with the stigma of learning difficulties, these students started to show low self-esteem and the teachers avoided working with them. The school decided to "disperse the repeaters among the classes to stimulate coexistence with the others", which also did not achieve the desired results.

In 2010, through the proposed Project, the school accepted the challenge of creating the first class, bringing together students in the $7^{\text {th }}$ and $8^{\text {th }}$ grades lagging behind in school, aiming the conclusion of their fundamental education in one year. The class enrolled 33 students, most from the school itself, and also with a teacher from the school. The entire class completed the Fundamental Education. "Here the Project has been a success, but there are schools where it didn't happen", stated the Principal.

When the Principal decided to implement the acceleration learning class, she already had in mind the teacher's profile for this task. The chosen teacher, who assumed the position of School Coordinator the following year, made a comprehensive evaluation of the work developed, emphasizing that "the project is responsible for keeping the students in school". He reveals some of the difficulties faced by describing the students of the Project as "boys and girls marginalized by the school", noting that teaching Mathematics was a great challenge, because in this discipline "the students needed to learn the basic". Behavioral aspects related to the way students interact with their colleagues and teachers, and their attitudes and habits were listed as determinant factors for achieving the results:

"However, the most important part of this Project was not the subject they were eventually able to learn, but it was really the human work that was done with them. The self-esteem of those kids was really something that pleased me, therefore, my Oscar award."

The teacher's perception of his own work in the school helps to illustrate his commitment. During the interviews and observations of school activities, we have not noticed any attempt to blame the student responsible for his failure or his delay at school, but the school agents understand the difficulties students face in their daily routine. The weak participation of the family, the conflicts between parents and children, "the lack of sense" given to school and the prospect of a future poorly associated with schooling were the problems pointed out.

Describing the behavior of the majority of the students enrolled in the Project, familyschool tension is a present aspect. Teachers and administrators notice, in different situations, reflexes of low valorization of education in family environments. However, they do not react to this problem with indifference or the feeling of helplessness, but they invest in valuing the teaching work, acknowledging that "the student won't change alone".

The school expectations regarding families are described as: "educate, show limits, give parameters of right and wrong and give an indication for the future". The Coordinator reveals that many students call him "dad", what in his point of view signalizes the need for a reference - "students are asking for affection and limits". On the other hand, he admits that parents' presence is required by the school only in emergency cases, due to the lack of qualified school staff (educational counselor and psychologist). Many activities and duties accumulate, and one 
PROBLEMS

OF EDUCATION

IN THE $21^{\text {st }}$ CENTURY

Volume 40, 2012

148

conflicts is illustrated by the metaphor used by the Coordinator: "You cannot stop the train. You have to repair the train while it is moving ".

The Coordinator also calls the attention to some of his colleagues' attitude, declaring that "many teachers like to give classes only to a minority of students, the ones who are independent and learn easily". The so-called "difficult student" - the one, who has difficulties to learn and to focus, is often marginalized:

"That student the teacher isn't interested in working with because he makes you work hard. You have to persuade him that he needs to study, and most of the teachers prefers the ones that already come in doctrinated from home..."

This Coordinator present as established attitude to deal with these students. Vega and Silva (2008) emphasize that many children who fail at school do not present "specific disability" that prevent them from learning, and admit that most of them "don't fit into certain learning styles". The Coordinator also points out the difference between the teacher of the first grades and the one who teaches the second segment of fundamental school. The former spends most part of the time with the same class, proximity which contributes to the understanding and development of a language providing an affective relationship, where compliments contribute to student's progress.

Research by Sousa (1999) analyses some results of the acceleration learning national policy for the first segment of fundamental education. The author identifies that many teachers assume the difficulty of dealing with less autonomous students to whom it is necessary to teach how to learn. Teachers interviewed by Sousa admit that the time needed to develop a work focusing on the student, teaching him to overcome difficulties is greater than what they usually dedicate.

Teachers' inabilities to deal with the students' difficulties have already been pointed out in different studies (Schwartzman, 2003; Barbosa, 2011). These authors identifies the lack of tools to deal with these difficulties and with the students learning pace, leading to the belief that such difficulties cannot be resolved by changes in the pedagogical interaction, in the language employed or in the class organization. Many teachers associate almost the entire learning problem with social background, family environment and the failed student's schooling.

Oliveira (1998) points out that besides evaluate school quality using standardized test and the observations of the facilities, the teacher work in the classroom and other elements may have effect on school performance, demanding further investigation.

The relationship between teachers and students has been the focus of our research in schools of acknowledged quality. In the survey carried out in this school in 2009, we found out that students have a positive perception of the teachers ${ }^{4}$. Asked about this relationship, the Coordinator pointed out that the good evaluation should be relativized because, for many students, "what is considered a 'boring teacher' often is the one who demands more, who gives more exercises, and the so-called 'cool teacher' could be the one who 'skips classes' or who doesn't teach effectively". Therefore, the perceptions of this relationship would depend much more on the student's profile than on the way students conceive a good and a bad teacher. The Coordinator's contextualization about our statistical summaries meets the perspective proposed by Collins (2000), that the analysis of survey data must have "conceptual priority" - the results must be relativized in the routines, perceptions and language of social agents.

Many students enrolled in acceleration learning classes were 'newcomers' and already had a failed student's schooling associated with indiscipline. In addition to differentiated pedagogical guidance, activities were proposed, such as: "book making", mentorship and the creation of a journal. The election of students' representatives and the students' role in Representative Councils were also reconsidered with the class involvement, generating more effective participation. 
It was possible to observe that despite the differentiated insertion of Project students,

they had representativeness ensured in all pedagogical activity at school, such as election of the principal, exhibition of works at school and graduation ceremony.

But this type of project also presents problems. Sousa's (1999) studies also shows the strangeness of students as they leave the acceleration classes like the student who says: "The difference of the teacher's Project is that she teaches how to study and now the teachers tell us to study" (idem, p. 91), illustrating the importance of a long-term analysis.

For the second year of the Project, a Portuguese teacher, with extensive experience in the school, was trained. The 30 students, this time almost all newcomers, have passed at the end of the year. In the graduation ceremony organized by the school, the teacher gave the following testimony:

“(...) after 30 years teaching, join the Project was a great challenge and an learning opportunity which contributed to make me a better human being. I have tried to make a difference in each student's life. Have I succeeded? We have gone trough difficult moments, but we haven't given up. Every time you [students] put into practice values as ethics, brotherhood, companionship, respect, perseverance and optimism I will feel remembered".

In this case study, the great part of the Project success can be associated with the coordination and direction commitments, which have proved to know the problems very well, getting involved with the students' daily school routine, following up attendance, bringing the classes together for collective activities and helping in different ways. Evaluating the Project results, after two years, the Principal pointed out as essential factors for success: teacher suitable for these students, school management ready to comply with the supporting requirements, and cooperation from families. Sousa (1999) has identified in many schools that have implemented the acceleration learning classes, an isolation of the students and teachers involved, noting that many issues and conflicts related to these students cannot be solved only by the teachers, but require other school agents' support and families' involvement.

On the graduation ceremony, one of students spoke about the initial "mistrust and prejudice" of colleagues about the Project. He recalled "the strangeness of the students themselves regarding the organization of the desks in a circle, the films and the outing-classes". However, he ended his speech, emphasizing that these aspects have been overcome, "we have made new friends and learned to have autonomy and responsibility".

In addition to the testimonies, the observation of activities developed by the students in classroom helps to understand how important was the sense of school experience. Such activities represent the proposal to enhance the schooling experience and stimulate the construction of a new perspective for the future. They also work with the student's self-image focusing on his abilities, leading him to associate his aspirations with the school's objectives. These aspects will be explored in future studies of the research group.

\section{Conclusions}

With this research we do not intend to evaluate the Project in progress, but explore relevant aspects about actions implemented to speed-up learning and to build partnerships in public education.

It is apparent that the pedagogical work focus was not aimed only at recovering the school programs lost in previous grades. Once student's levels of difficulties (cognitive, emotional, psychological) were identified, the objectives were driven to recovering the selfesteem, developing habits of study, school frequency, behavior in class and learning the basic issues, which would enable them to continue their schooling. With differentiated teaching, receiving full attention of a single teacher, and relying on activities focused on providing students with tools they will be able to expand their access to knowledge, and construct their own autonomy. 
PROBLEMS

OF EDUCATION

IN THE $21^{\text {st }}$ CENTURY Volume 40, 2012

In a casual conversation, the principal told us that all the former students of the Project are in Middle Education, including some she "doubted whether they would continue due to the level of difficulty they had". Many of them are eager to attend college. We know that acceleration learning proposals raise doubts as to their effectiveness for reintegrating students to the regular education system. Accustomed to a fully dedicated teacher, to differentiated methodology and to affective approach, students egressed from this kind of project may feel once again excluded in regular classes, resulting in other school failures. It's necessary to follow up over the next few years of the former students to better understand this issue.

Based on the experience we have analyzed we can affirm with relative confidence that acceleration projects can contribute to age-grade gap students' move forward reaching performance levels compatible with regular classes.

It is important to remind that this experience has taken place in a school well-known for its quality that, nevertheless, deals with the challenge to assist students of diverse social strata, enhancing their schooling.

Some answers to the challenge of continuing studies may be present in the Project goals, which are instructing to study, focusing on habits and routines, on language and self-confidence developments. It is noteworthy to emphasize that these goals can and should be extended to the teaching practice, which often is exclusively focused on subjects of school programs. Such global aspects of teaching, assumptions of the educational policy we've studied, refer to a review of the pedagogical tools in the classroom, may also be applied in regular classes as a kind of "behavioral school curriculum".

Regarding public-private partnership, researches indicate greater chances of success when the partnership focuses on a specific subject, invests in teachers' training and has managers' support and school staff commitment. Were found all the three aspects in this Project what seems to enhance the prospect of success.

Although the results are strongly impacted by the characteristics of the school and educational agents' joint action, we can say based on our case study these learning acceleration projects can contribute to get the desired education quality to those students who haven't achieved success in traditional education.

\section{Notes}

\section{(Endnotes)}

1 Basic education comprises nine years of "fundamental education" divided in two segments, for children ages 6 to 14 (the second segment comprises the sixth to ninth grade), and three years of "middle education" for youngsters ages 15 to 17 .

2 SOCED - Research Group in Sociology of Education - Production available from Boletim SOCED. (Source: http://www.maxwell.lambda.ele.puc-rio.br/soced.php?strSecao=input).

3 The Roberto Marinho Foundation is a private institution, non-governmental, which elaborates and develops actions of dissemination and education since 1977, as educational technologies and training professionals. (Source: http://www.frm.org.br/main.jsp?lumChannelId=8A94A98E20E7EF740121115ABD140ABE. Retrieved in: Feb, 7th 2012).

4 We asked the students how relationship with the teachers was, $36.1 \%$ said it was very good, while $50.9 \%$ said it was good and 13\%, reasonable. None of the students said the relationship with the teachers was poor or very bad.

\section{Acknowledgements}

Thanks to the National Counsel of Technological and Scientific Development - CNPq, for the financial support. 
Alice XAVIER, Maria Luiza CANEDO. Education Quality in Public Schools: An Experiment to Reduce the Age-Grade Gap in the City of Rio de Janeiro

\section{References}

Barbosa, M. L. de O. (2011). Desigualdade e Desempenho. Uma introdução à sociologia da escola brasileira. Belo Horizonte: FinoTraço Editora.

Collins, R. (2000) Situational Stratification: a micro-macro theory of inequality. Sociological Theory, 18 (1), 17-83.

Lacerda, P. (org). (2009) Parcerias com escolas municipais do Rio de Janeiro. Rio de Janeiro: Instituto Desiderata. Retrieved 09/02/2012, from http://www.desiderata.org.br/docs/pesquisa-parceriasescolas-municipais-2009.pdf

Oliveira, J. B. A. (1998). Análise de custos e resultados do Programa de Aceleração de Aprendizagem. Ensaio: Avaliação e Políticas Públicas em Educação, 6 (18), 23-56.

Schwartzman, S. (2003). The Challenges of Education in Brazil. Feb. 26. Version 3, 1995. Retrieved 09/02/2012, from http://www.drclas.harvard.edu/files/Simon-Schwartzman-Challenges-ofEducation-in-Brazil.pdf.

Sousa, C. P. de. (1999). Limites e Possibilidades dos Programas de Aceleração da Aprendizagem. Cadernos de Pesquisa, 108, 81-99.

Vega, M. L., \& Silva, M. M. P. (2008). Aprendizagem Acelerativa: Recuperando a autoestima do aluno. Saber Digital: Revista Eletrônica do CESVA, 1 (1), 119-137.

Advised by Rosaly H. L. Brandão, Pontifical Catholic University of Rio de Janeiro, Brazil

Received: January 26, 2012

Accepted: March 09, 2012

\begin{tabular}{|ll} 
Alice Xavier & PhD Student, Researcher at Pontifical Catholic University of Rio de Janeiro, \\
& Ana Cristina César Street, 155, apt 110. JPA, 22763145, Rio de Janeiro, RJ. \\
& Brazil. \\
& E-mail: alicepx@yahoo.com.br \\
& Website: http://lattes.cnpq.br/1731362489238054 \\
\hline Maria Luiza Canedo & PhD Student, Researcher at Pontifical Catholic University of Rio de Janeiro, \\
& Nascimento Silva Street, 426, apt 201, Ipanema, 22421020, Rio de Janeiro, \\
& RJ. Brazil. \\
& E-mail: luiza.canedo@uol.com.br \\
& Website: http://lattes.cnpq.br/8531119006036997
\end{tabular}

